\title{
Low Dose Spinal Anesthesia Bupivakain 0,5\% 5 mg dengan Adjuvan Fentanyl 50 mcg untuk Pasien dengan Uncorrected Tetralogy of Fallot yang Menjalani Seksio Sesarea
}

\author{
Ruddi Hartono ${ }^{1}$, Sri Rahardjo ${ }^{2}$, Yusmein Uyun ${ }^{2}$ \\ ${ }^{1}$ Departemen Anestesiologi dan Terapi Intensif Fakultas Kedokteran Universitas Brawijaya-RSUP Dr. Saiful \\ Anwar Malang, ${ }^{2}$ Departemen Anestesiologi dan Terapi Intensif, Fakultas Kedokteran Universitas Gajah Mada- \\ RSUP Dr. Sardjito Yogyakarta
}

\begin{abstract}
Abstrak
Pasien hamil dengan uncorrected tetralogy of fallot yang menjalani seksio sesarea merupakan tantangan tersendiri bagi dokter anestesi. Tetralogy of Fallot terdiri dari ventricular septal defect, hipertrofi ventrikel kanan, overriding aorta dan stenosis pulmonal. Prinsip anestesi pada pasien ini adalah mempertahankan systemic vascular resistence (SVR) dan menghindari peningkatan pulmonary vascular resistance (PVR). Pasien Ibu hamil, 19 tahun dengan berat badan $50 \mathrm{~kg}$, tinggi badan $150 \mathrm{~cm}$, G3P000Ab200 Gravida 36-37 minggu, tunggal hidup, fetal distress dan tali pusat menumbung dengan tetralogy of fallot, akan dilakukan seksio sesarea cito. Penatalaksanaan anestesi pasien ini dengan low dose spinal anesthesia bupivakain 0,5\% $5 \mathrm{mg}$ dan adjuvan fentanyl $50 \mathrm{mcg}$. Hemodinamik stabil setelah tindakan spinal. Tekanan darah sebelum dilakukan spinal 100/60 mmHg dengan laju nadi 67 kali per menit dan saturasi oksigen 80\% menggunakan non rebreathing mask (NRBM) 10 liter per menit. Tekanan darah pada saat operasi dimulai adalah $96 / 57 \mathrm{mmHg}$ dan laju nadi 77 kali per menit serta saturasi $78 \%$ menggunakan NRBM 10 liter per menit. Setelah bayi dilahirkan, hemodinamik stabil hingga akhir operasi, tidak ditemukan periode hipotensi yang berat dan tidak digunakan obat vasopressor selama operasi. Pasien dipindahkan ke ICU untuk observasi pasca operasi selama 2 hari. Selama perawatan di ICU, kondisi pasien tetap stabil dan kemudian dipindahkan ke ruang perawatan biasa. Low dose spinal anesthesia mencegah risiko hipotensi karena intensitas blok simpatis yang lebih minimal sehingga penurunan SVR dapat dihindari. Teknik ini dapat digunakan sebagai alternatif pembiusan pada pasien dengan tetralogy of fallot tetapi tergantung kondisi pasien saat akan dilakukan pembiusan.
\end{abstract}

Kata kunci: low dose spinal anesthesia: seksio sesarea; tetralogy of fallot

\section{Low Dose Spinal Anesthesia Bupivacaine 0,5\% 5 mg with Adjuvant Fentanyl 50 mcg for Cesarean Section Patient with Uncorrected Tetralogy of Fallot}

\begin{abstract}
Cesarean delivery in parturient with uncorrected tetralogy of fallot poses significant challenge for anesthesiologist. Tetralogy of Fallot consists of ventricular septal defect, right ventricular hypertrophy, overriding aorta and stenosis pulmonum. Main principle of anesthesia for tetralogy of fallot is maintenance of systemic vascular resistance dan avoidance of increasing pulmonary vascular resistance. Parturient, 19 years old, body weigt $50 \mathrm{~kg}$, height 150 cm, G3P000Ab200 36 - 37 weeks, fetal distress and umbilical cord prolapse with tetralogy of fallot will perform cesarean section. Patient anesthesized with low dose spinal anesthesia using bupivacaine $0,5 \% 5 \mathrm{cmg}$ with adjuvant fentanyl $50 \mathrm{mcg}$. Haemodynamic before spinal with blood pressure is $100 / 60 \mathrm{mmHg}$, heart rate 67 beat per minute (BPM), saturation is $80 \%$ using 10 liter of oxygen non rebreathing mask (NRBM). Blood pressure during incision $96 / 57 \mathrm{mmHg}$ heart rate 77 BPM with saturation 78\% using 10 liter of NRBM. Haemodynamic is stable after baby is born until the operation is done, without any episode of severe hypotension and there is no using of vasopressor drugs. Patient is moved to ICU after the operation for further observation and for 2 days periode the haemodynamic is stable and then patient is moved to regular ward. Low dose spinal anesthesia avoid the incidence of hypotension by causing less intense blocked sympathetic system than traditional dose and thus providing a stable SVR. This technique could be an alternative for anesthesizing for parturient with tetralogy of fallot but its depend on patient condition before operation.
\end{abstract}

Key words: cesarean section; low dose spinal anesthesia; tetralogy of fallot 


\section{Pendahuluan}

Insiden pasien ibu hamil dengan kelainan jantung sekitar $\quad 0,4-4,1 \%{ }^{1}$ Mortalitasnya mencapai sekitar $15 \%$ dan merupakan tingkat mortalitas yang utama pada kehamilan secara umum. ${ }^{2}$ Tingkat angka harapan hidup semakin meningkat seiring dengan semakin berkembangnya modalitas untuk pemeriksaan jantung dan teknik operasi pada pasien dengan kelainan jantung. Tetralogy of Fallot (ToF) merupakan salah satu kelainan jantung kongenital sianosis yang sering ditemukan pada pasien dengan kehamilan, dan angka kejadiannya sekitar $5 \% .^{3}$ Tetralogy of Fallot terdiri dari ventricular septal defect (VSD), overriding aorta, hipertrofi ventrikel kiri dan pulmonary stesnosis. ${ }^{4}$

Kondisi Ibu hamil dengan tetralogy of fallot akan semakin memperberat fungsi jantung karena perubahan fisiologis kehamilan terutama peningkatan volume dan penurunan systemic vascular resistance (SVR) dapat menyebabkan perubahan shunt dari kanan ke kiri. Hipoksia dan polisitemia akan menyebabkan abortus, gangguan pertumbuhan janin, kematian janin dan kematian ibu. Anestesi umum merupakan pilihan utama untuk pembiusan pada pasien dengan tetralogy of fallot tetapi harus diperhatikan resiko peningkatan pulmonary vascular resistance (PVR) karena hipoksia, hiperkarbia dan asidosis. Tehnik epidural juga dapat digunakan karena penurunan SVR tidak secepat jika dibandingkan dengan anestesi spinal. ${ }^{5}$

Pada laporan kasus ini menggunakan tehnik anestesi low dose spinal dengan harapan tidak terjadi perubahan hemodinamik yang signifikan sehingga tidak terjadi perubahan shunt dari kanan ke kiri karena penurunan SVR.

\section{Kasus}

\section{Anamnesa}

Ibu hamil, 19 tahun dengan berat badan $50 \mathrm{~kg}$ dengan tinggi badan $150 \mathrm{~cm}$, G3P000Ab200 Gravida 36-37 minggu, tunggal hidup, fetal distress dan tali pusat menumbung dengan penyakit jantung bawaan sianotik tetralogy of fallot yang akan dilakukan seksio sesarea cito. Dari anamnesa didapatkan bahwa kelainan jantung pasien diderita sejak kecil tetapi tidak rutin kontrol. Pasien mengeluh sesak jika kelelahan. Tidak didapatkan riwayat operasi dan pembiusan sebelumnya serta tidak didapatkan riwayat diabetes melitus, hipertensi, maupun asma. Dari riwayat obstetri didapatkan pada tahun 2013, pasien hamil anak pertama, usia kehamilan saat itu 2 bulan dan mengalami abortus spontan tetapi tidak dilakukan kuretase. Tahun 2014 hamil anak kedua, usia kehamilan 4 bulan dan mengalami abortus spontan, dilakukan kuretase di RSUD Wlingi Blitar, serta kehamilan yang saat ini adalah kehamilan anak ketiga. Pasien tiba di IGD RSUD Dr. Saiful Anwar Malang tanpa keluhan sesak nafas, tidak didapatkan nyeri dada maupun berdebar-debar. Kontraksi perut dirasakan semakin kuat dan sering. Usia kehamilan adalah 36-37 minggu dengan riwayat kontrol teratur di bidan. Tidak didapatkan keluhan selama kehamilan, aktivitas sehari-hari seperti biasa. Tidak didapatkan keluhan mual, muntah, nyeri kepala maupun pusing

\section{Pemeriksaan Fisik}

Dari pemeriksaan fisik didapatkan nafas spontan dengan laju nafas $20 \mathrm{x} /$ menit, tipe torakoabdominal. Tidak ditemukan retraksi dada maupun nafas cuping hidung. Saat di Instalasi Gawat Darurat didapatkan saturasi oksigen antara 45-64\% dengan non rebreathing mask (NRBM) 10 Liter per menit. Tekanan darah 94/52 $\mathrm{mmHg}$, nadi $120-130 \mathrm{x} / \mathrm{menit}$, suara jantung I dan II intensitas normal, reguler, dan ditemukan murmur sistolik grade III/VI dengan punctum maksimal di ICS II linea para-sternal sinistra, tidak didapatkan penjalaran maupun gallops. Akral hangat dan kering, kuku sianotik dengan capillary refill time kurang dari 2 detik Tidak didapatkan edema, namun terdapat clubbing finger $(+)$ grade IV. GCS E4V5M6. Pasien buang air besar dan kecil spontan. Tinggi fundus uteri $24 \mathrm{~cm}$, Denyut jantung janin (+) 70 - 80 kali per menit. Didapatkan tali pusat menumbung.

\section{Pemeriksaan Penunjang}

Ekokardiografi

Didapatkan VSD, overriding aorta, pulmonal 
stenosis, right ventricel hypertrophy. Kesan: kontraksi left ventricel baik. Kesimpulan suatu tetralogy of fallot.

\begin{tabular}{ll}
\hline Laboratorium & \\
\hline Haemoglobin & $13,60 \mathrm{~g} / \mathrm{dL}$ \\
Hematokrit & $44,50 \%$ \\
Trombosit & $115.000 / \mathrm{mm} 3$ \\
Leukosit & $19.300 / \mathrm{mm} 3$ \\
PPT & $13, / 10,5 \mathrm{detik}, \mathrm{INR} 1,25$ \\
APTT & $41,70 / 25,9$ detik \\
SGOT/SGPT & $26 / 8 \mathrm{IU} / \mathrm{L}$ \\
Albumin & $3,01 \mathrm{mg} / \mathrm{dL}$ \\
Gula Darah & $127 \mathrm{mg} / \mathrm{dL}$ \\
Sewaktu & \\
Ureum/Creatinine & $20,00 / 0,8 \mathrm{mg} / \mathrm{dL}$ \\
\hline
\end{tabular}

\begin{tabular}{ll}
\hline Blood Gas Analysis & \\
$\mathrm{pH}$ & 7,38 \\
$\mathrm{pCO}_{2}$ & $26,3 \mathrm{mmHg}$ \\
$\mathrm{pO}_{2}$ & $29,9 \mathrm{mmHg}$ \\
Bikarbonat $\left(\mathrm{HCO}_{3}\right)$ & $15,7 \mathrm{mmol} / \mathrm{L}$ \\
Base Excess & $-9,6 \mathrm{mmol} / \mathrm{L}$ \\
Saturasi $\mathrm{O}_{2}$ & $57,9 \%$ \\
Hemoglobin & $15,4 \mathrm{~g} / \mathrm{dL}$ \\
Suhu & $37,0{ }^{\circ} \mathrm{C}$ \\
\hline
\end{tabular}

\section{Pengelolaan Anestesi}

Assesment pasien ini adalah ASA 4E gravida dengan penyakit jantung sianotik tetralogy of fallot dengan fetal distres dan tali pusat menumbung. Informed consent bahwa keadaan Ibu dengan resiko tinggi pembiusan serta kondisi janin intrauterin yang sudah mengalami bradikardia. Pasien tetap dipuasakan, pasang jalur intravena dan pemberian cairan $\mathrm{NaCl}$ 0,9\% $90 \mathrm{ml} / \mathrm{jam}$ selama puasa. Diberikan injeksi ranitidine $50 \mathrm{mg}$ dan metoclopramide $10 \mathrm{mg}$ intravena 1 jam sebelum operasi. Sedia darah packed red cell (PRC) $250 \mathrm{cc}$. Rencana pembiusan dengan regional anestesia sub arachnoid block low dose dengan regimen spinal bupivakain heavy $0,5 \% 5 \mathrm{mg}$ dengan adjuvan fentanyl $50 \mathrm{mcg}$, dengan insersi spinocath di antara vertebrae lumbal 3 dan lumbal 4.

\section{Pengelolaan Pascabedah}

Pasien dipindahkan ke ruang pemulihan setelah operasi dengan hemodinamik tekanan darah 101/65 mmHg, nadi 84 kali per menit, laju nafas 23 kali per menit dan saturasi oksigen $76 \%$ dengan non rebreathing mask (NRBM) 10 liter per menit. Evaluasi skor Bromage 0 pada menit 85 setelah operasi. Analgetik yang diberikan adalah injeksi ketorolak $30 \mathrm{mg}$ per 8 jam, serta fentanyl syringe pump $25 \mathrm{mcg}$ per jam. Setelah observasi di ruang pemulihan, pasien kemudian dipindahkan ke ICU untuk observasi lebih lanjut. Pasien dirawat di ICU selama 2 hari dengan kondisi hemodinamik stabil, dan selanjutnya pasien dipindahkan ke ruang perawatan biasa.

\section{Pembahasan}

Prinsip pembiusan pada pasien dengan tetralogy of fallot adalah menghindari penurunan SVR sehingga shunt dari kanan ke kiri tidak terjadi. Pemilihan tehnik anestesi sangat tergantung pada kondisi pasien itu sendiri. Pembiusan dapat dilakukan dengan menggunakan tehnik anestesi umum maupun blok neuroaksial. Single shot spinal tidak direkomendasikan karena penurunan SVR akibat vasodilatasi perifer pasca spinal akan menyebabkan hipotensi. Hal ini sangat dihindari pada pasien dengan kelainan jantung yang didapatkan shunt. Selain itu, nyeri post operasi harus dihindari karena nyeri akan menyebabkan spasme infundibular outflow ventrikel kanan sehingga bisa menyebabkan shunt dari kanan ke kiri. Target lain untuk pembiusan pasien dengan tetralogy of fallot adalah mencegah terjadinya hipovolemia, hipoksia, hiperkarbia dan asidosis yang mengakibatkan peningkatan pulmonary vascular resistance, serta sebaliknya menurunkan SVR.

Teknik anestesi pada pasien dalam kasus ini dilakukan dengan low dose spinal anesthesia menggunakan regimen $5 \mathrm{mg}$ bupivakain heavy $0,5 \%$ dan adjuvan fentanyl $50 \mathrm{mcg}$, dengan total volume $2 \mathrm{ml}$. Insersi jarum spinal ukuran 27-G pada Tuffier's Line, yang selanjutnya pasien segera diposisikan supine setelah injeksi. Pada 


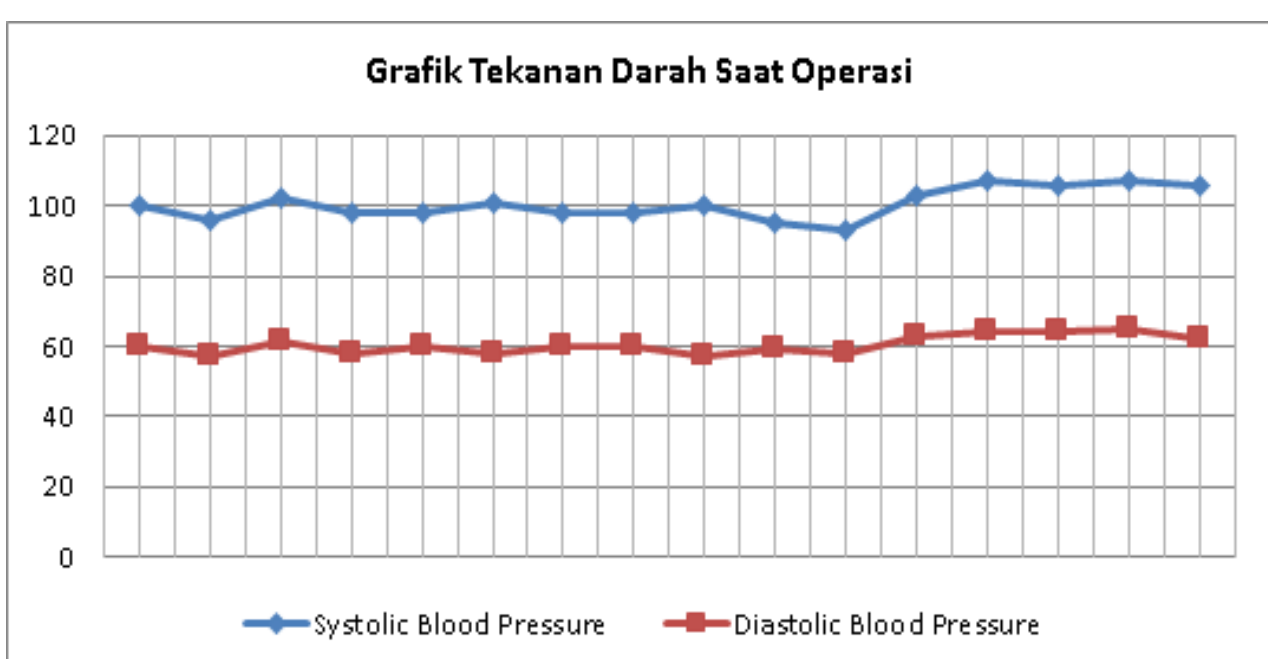

Grafik 1. Tekanan Darah Sistolik dan Diastolik saat Operasi

teknik ini, tidak dilakukan head up maupun head down. Kami dapatkan bahwa skor Bromage 1 tercapai dalam 59-63 detik, Bromage 2 dalam 89-99 detik dan bromage 3 dicapai dalam 130170 detik setelah insersi. Sedangkan ketinggian blok T6 tercapai dalam 4 menit. Delivery incision time 10 menit. Hemodinamik setelah injeksi spinal tetap stabil dengan fluktuasi yang minimal dan tidak didapatkan perubahan bermakna bila dibandingkan dengan hemodinamik awal dari pasien. Tekanan darah sebelum dilakukan spinal 100/60 mmHg dengan laju nadi 67 kali per menit dan saturasi oksigen $80 \%$ menggunakan non rebreathing mask (NRBM) 10 liter per menit.
Tekanan darah setelah spinal adalah 96/57 mmHg dengan laju nadi 77 kali per menit dengan saturasi oksigen 78\% menggunakan NRBM 10 liter per menit. Setelah bayi lahir, pasien diberikan injeksi oksitoin secara perlahan dengan mengencerkan 1 ampul oksitosin menjadi $10 \mathrm{ml}$, diberikan secara intermitten $1 \mathrm{ml}$ per menit dengan mengevaluasi kontraksi uterusnya. Selama intraoperatif dan postoperatif tidak didapatkan keluhan sesak nafas, mual, muntah maupun pusing serta tidak didapatkan hipotensi. Selama operasi juga tidak digunakan obat-obatan untuk menaikkan tekanan darah. Observasi pasca operasi di ICU selama 2 hari dan dilaporkan hemodinamik tetap stabil

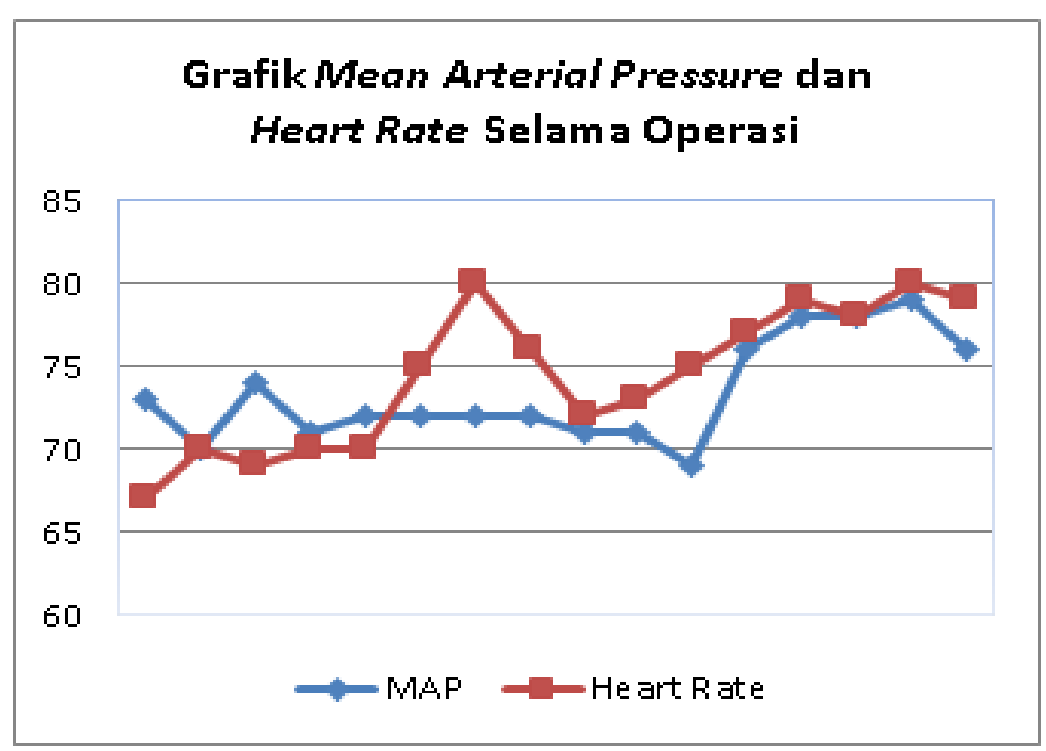

Grafik 2. Grafik MAP dan Heart Rate selama Operasi 


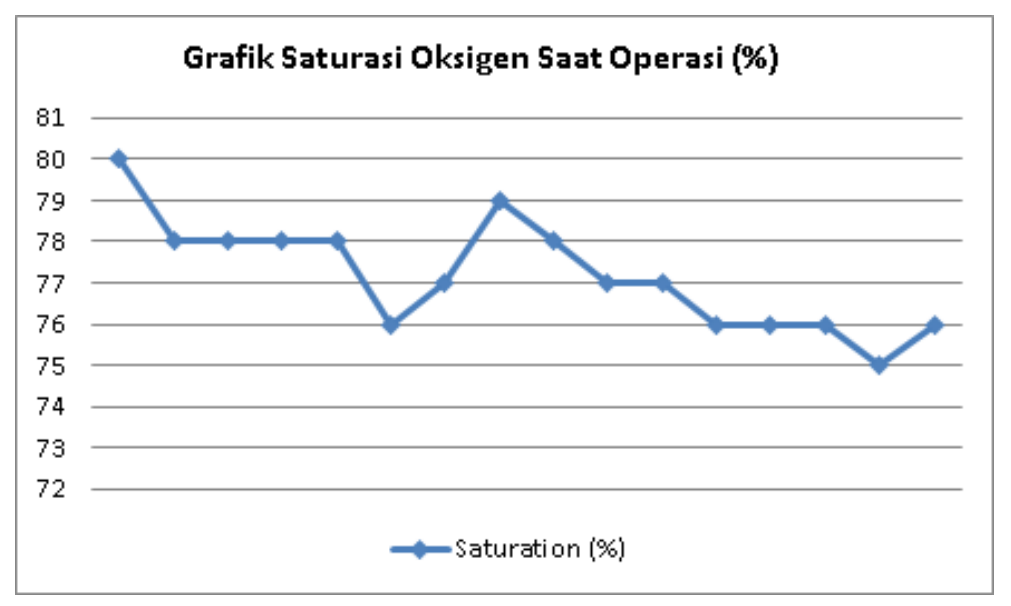

Grafik 3. Grafik Saturasi Oksigen Saat Operasi (\%)

sehinggahari ke 3 pasien kemudian dipindahkan ke ruang perawatan biasa. Dosis rendah bupivakain hiperbarik $5 \mathrm{mg}$ dikombinasikan dengan fentanyl $50 \mathrm{mcg}$ menghasilkan blok yang adequat dengan efek samping sistemik yang minimal. Efek yang diharapkan adalah meminimalkan penurunan SVR dan mencegah timbulnya hipotensi pada anestesi spinal. Salah satu strategi untuk mempertahankan hemodinamik yang stabil selama dilakukan anestesi spinal pada seksio sesarea adalah dengan menggunakan bupivakain dosis rendah yang dikombinasikan dengan adjuvan opioid. Pada laporan kasus ini juga kami tidak menemukan adanya episode hipotensi dan desaturasi.

Penelitian yang ada sebelumnya, dilakukan dengan membandingkan antara teknik spinal yang menggunakan bupivakain $10 \mathrm{mg}$ tanpa adjuvan dibandingkan dengan menggunaan bupivakain 7,5 mg yang ditambahkan adjuvan fentanyl 25 mcg. Disimpulkan bahwa pada teknik spinal dengan dosis $10 \mathrm{mg}$ terjadi penurunan tekanan darah sistolik dan diastolik secara signifikan setelah menit ke 3 dan 5 jika dibandingkan dengan penggunaan bupivakain 7,5 $\mathrm{mg}$ dengan adjuvan fentanyl $25 \mathrm{mcg}$. Hal ini disebabkan oleh blok simpatis yang lebih tinggi. ${ }^{7}$ Hasil yang sama juga ditemukan pada penelitian yang membandingkan penggunaan bupivakain dosis normal dengan bupivakain $8 \mathrm{mg}$ dengan tambahan adjuvan fentanyl 10 mcg. ${ }^{8,9}$
Tidak ada bukti bahwa anestesi umum atau neuroaksial lebih superior pada pasien tetralogy of fallot dengan kehamilan, tetapi pada kasus ini mendukung data observasional sebelumnya bahwa anestesi neuroaksial dapat diberikan dengan aman terutama jika menggunakan teknik low dose spinal anesthesia. ${ }^{6}$ Sebelumnya penggunaan anestesi lokal bupivakain dosis rendah (3-5 $\mathrm{mg}$ ) pada spinal yang dikombinasikan dengan pemberian bupivakain epidural secara lambat dan inkremental untuk proses operasi telah dilakukan dan didapatkan efek hipotensi yang minimal. ${ }^{10}$ Sebuah laporan kasus di salah satu rumah sakit di India membahas tentang penatalaksanaan anestesi dengan low dose spinal anesthesia menggunakan bupivakain $6 \mathrm{mg}$ dengan adjuvan fentanyl $25 \mathrm{mcg}$ pada pasien seksio sesarea dengan uncorrected tetralogy of fallot untuk menghindari penurunan SVR dan peningkatan PVR. Teknik ini secara rutin digunakan pada institusi rumah sakit tersebut. Mereka sedapat mungkin menghindari penggunaan teknik anestesi umum pada pasien dengan kelainan jantung dengan alasan resiko terjadinya peningkatan PVR akibat tekanan positif yang diberikan saat operasi, serta adanya hipoksia, hiperkarbia dan asidosis dapat memperburuk kondisi pasien tersebut sehingga lebih memilih teknik regional dimana pasien tetap dapat bernafas spontan. ${ }^{11}$

Pasien-pasien dengan indeks kardiak yang rendah yang menjalani operasi dengan anestesi spinal dengan dosis obat lokal anestesi yang kecil 
menunjukkan penurunan MAP yang minimal karena intensitas blok sistem simpatisnya yang lebih rendah jika dibandingkan dengan menggunakan dosis obat lokal anestesi pada umumnya. Karena intensitas blok simpatis yang lebih rendah inilah yang kemudian tidak menyebabkan penurunan SVR yang bermakna sehingga kejadian hipotensi yang selama ini sering terjadi pada anestesi spinal dapat dicegah. ${ }^{12,13}$

Fentanyl bekerja secara sinergis dengan bupivakain dalam menurunkan ambang nyeri tanpa meningkatkan blokade simpatik dan motorik. Telah banyak penelitian yang membuktikan efektivitas penggunaan opioid pada anestesi spinal terutama pada seksio sesarea. Fentanyl dapat mempercepat onset dan memperpanjang durasi blok bupivakain, memberikan analgesi yang baik selama operasi serta memperpanjang durasi analgesia post operasi. Efek samping yang ditemukan seperti mual, muntah dan menggigil juga minimal. ${ }^{14,15}$ Kombinasi keduanya memiliki kecepatan onset 5 menit secara intratekal dan 10 menit melalui epidural. Tidak didapatkan adanya metabolit aktif dan memiliki sifat 800 kali lebih larut dalam lipid dibandingkan morfin. Kelarutan yang sangat tinggi dalam lemak akan cepat berikatan dengan reseptor opioid di cornu dorsalis medula spinalis, dan onset yang cepat ini sangat menguntungkan baik sebagai analgesia pada persalinan normal maupun pada kasus seksio sesarea emergensi.

\section{Simpulan}

Low dose spinal anesthesia dapat digunakan sebagai alternatif pembiusan pada pasien kehamilan dengan uncorrected tetralogy of fallot tetapi harus disesuaikan dengan kondisi pasien sebelum dilakukan pembiusan. Low dose spinal anesthesia yang dilakukan pada pasien ini tidak menyebabkan hipotensi karena intesitas blok simpatis yang lebih rendah sehingga vasodilatasi, penurunan SVR, dan perubahan shunt dari kanan ke kiri tidak terjadi.

\section{Daftar Pustaka}

1. Chesnut DH. Principle and Practice of
Obstetric Anesthesia. Pennsylvania: Elsevier Mosby-Philadelphia; 2004, 707-33.

2. Boom CE. Perioperatif Kardiovaskular Anestesia. Jakarta: Aksara Bermakna; 2013, 226.

3. Coskun D, Mahli A. Anesthesia for Pregnant Patient with Cardiac Disease. Obstetric Anesthesia for Co-morbid Conditions. Cham, Switzerland: Springer International Publishing; 2018, 194-95.

4. Cintyandy R. Anestesia Jantung Kongenital. Jakarta: Aksara Bermakna; 2014,165-73.

5. Baidya DK, Dhir R, Dehran M, Mahapatra BP. Central neuraxial anesthesia for caesarean section with uncorrected tetralogy of fallot. J Obstet Anaesth Crit Care. 2012; 2:47-9.

6. Arendt KW, Fernandes, SM, Khairy P, Warnes CA, Rose $\mathrm{CH}$, Landzberg MJ, Craigo P, Hebl JR. A case series of the anesthetic management of parturiens with surgically repaired tetralogy of fallot. Anesth Analg 2011; 113: 307-17.

7. Venkata GH, Pasupuleti S, Pabba UG, Porika S, Talari G. A randomized Controlled prospective study comparing a low dose bupivacine and fentanyl mixture to a conventional dose of hyperbaric bupivacaine for cesarean section. Internal Medicine Faculty Publication. 2015;67.

8. Bogra J, Arora N, Srivastava P. Synergitic effect of intrathecal fentanyl and bupivacaine in spinal anesthesia for cesarean section. BMC Anesthesiol 2005;5:5.

9. Madarek E, Seyedhejazi M. Effect of small dose bupivacaine-fetanyl and bupivacaine in spinal anesthesia on hemodynamic nausea and vomiting in cesarian section. Pak J Med Sci. 2007;23:747-50.

10. Bray JK, Fernando R, Patel NP, Columb MO. Suprasternal doppler estimation of cardiac 
output: standard versus sequential combined spinal epidural for cesarean section delivery. Anesth Analg 2006; 103:959-64.

11. Adinarayanan A, Parida S, Kavitha J, Balachander H. Spinal anesthetic for cesarean section in a parturien with uncorrected tetralogy of fallot presenting with abruptio placentae and gestational hypertension. J Anesthesiol Clin Pharmacol 2014 Jul-Sept; 30(3): 400-02.

12. Sanatkar M, Sadeghi M, Esmaeili N, Sadrossadat H, Shoroughi M, Ghazizadeh S, Khoshraftar E, Anvari HP, Alipur N. The hemodynamic effects of spinal block with low dose of bupivacaine and sufentanyl in patients with Low Myocardial Ejection Fraction. J Acta Medica Iranica 2013; 51; 7.
13. Hofhuizen C, Lemson J, Snoeck M, Scheffer, GJ. Spinal anesthesia-induced hypotension is caused by a decrease in stroke volume in elderly patients. J Local and Regional Anesthesia 2019; 12: 19-26.

14. Kumar NM, Gajbhare, Kamble NP. Comparative study of intrathecal bupivacaine versus bupivacaine with fentanyl for cesarean section. Ind J of Clin Anesth 2016: 3(2): 27177.

15. Tan PH, Chia YY, LO Y, Yang LC, Lee TH. Intrathecal bupivacaine with morphin or neostigmin for postoperative analgesia after total knee replacement. Can J Anesth 2001;48(6):551-6. 